\title{
Comment on "Palaeoenvironmental control on distribution of crinoids in the Bathonian (Middle Jurassic) of England and France" by Aaron W. Hunter and Charlie J. Underwood
}

Mariusz A. Salamon, Przemysław Gorzelak, and Michał Zatoń

Acta Palaeontologica Polonica 55 (1), 2010: 172-173 doi: http://dx.doi.org/10.4202/app.2010.0014

Aaron W. Hunter and Charlie J. Underwood in their article published in Acta Palaeontologica Polonica (Hunter and Underwood 2009) present some interesting results regarding facies control on the distribution of certain crinoids in the Bathonian of England and France. This is an important contribution, but we feel necessary to comment on some issues raised in their paper.

Mariusz A. Salamon [paleo.crinoids@poczta.fm] and Michał Zatoń [mzaton@wnoz.us.edu.pl ], Faculty of Earth Sciences, University of Silesia, ul. Będzińska 60, PL-41-200, Sosnowiec, Poland; Przemysław Gorzelak [pgorzelak@twarda.pan.pl], Instytut Paleobiologii PAN, ul. Twarda 51/55, PL-00-818 Warszawa, Poland.

This is an open-access article distributed under the terms of the Creative Commons Attribution License (for details please see creativecommons.org), which permits unrestricted use, distribution, and reproduction in any medium, provided the original author and source are credited.

FoF 